\title{
Formação continuada de professores em uma unidade de ensino da rede pública estadual no município de Santa Helena de Goiás-Goiás: resistência ou desafio?
}

Continuing education of teachers in a teaching unit of the state public network in the city of Santa

Helena de Goiás-Goiás: resistance or challenge?

Formación docente continua en una unidad didáctica de la red pública estatal en el municipio de

Santa Helena de Goiás-Goiás: ¿resistencia o reto?

Recebido: 16/11/2021 | Revisado: 25/11/2021 | Aceito: 03/12/2021 | Publicado: 13/12/2021

\author{
Claudia Madeira Bernardes \\ ORCID: https://orcid.org/0000-0001-7948-7154 \\ Instituto Federal de Educação, Ciência e Tecnologia Goiano, Brasil \\ E-mail: claudiamadeirabernardesmadeira@gmail.com \\ Jesiel Souza Silva \\ ORCID: https://orcid.org/0000-0002-6682-3750 \\ Instituto Federal de Educação, Ciência e Tecnologia Goiano, Brasil \\ E-mail: jesiel.souza@ifgoiano.edu.br \\ Aline Ditomaso \\ ORCID: https://orcid.org/0000-0002-0297-391X \\ Instituto Federal de Educação, Ciência e Tecnologia Goiano, Brasil \\ E-mail: aline.ditomaso@ifgoiano.edu.br
}

\begin{abstract}
Resumo
Este trabalho tem como objetivo conhecer as principais interferências na formação continuada dos professores a partir das percepções dos professores da Unidade de Ensino da Rede Pública Estadual do município de Santa Helena de Goiás - Goiás. Para isso foram estabelecidos os seguintes objetivos específicos para este trabalho: a) enumerar as participações em formações continuadas dos professores da Unidade Escolar da Rede de Ensino Público Estadual durante os anos de 2018 e 2019; b) identificar a situação da carga horária do docente na escola e a sua relação com a formação continuada; c) verificar a participação dos docentes em formação dos docentes em formação continuada oferecida por outras instituições. No que se refere aos procedimentos metodológicos, trata-se de uma pesquisa de campo de caráter exploratório com abordagem quantitativa, realizada com 24 professores. Os dados coletados através de questio-nário foram sistematizados e analisados de acordo com uma abordagem quantitativa, que nos possibilitou considerar que a formação continuada é um desafio pois depende de fatores ora relacionados ao professor como a rotina intensa com carga horária alta, ausência de valorização salarial e social; e, elementos externos ao professor como a ausência de formação continuada oferecida pela Secretaria de Estado da Educação.
\end{abstract}

Palavras-chave: Formação continuada; Docência; Práticas pedagógicas.

\begin{abstract}
This work aims to know the main interferences in the continuing education of teachers from the perceptions of teachers from the Teaching Unit of the State Public Network in the municipality of Santa Helena de Goiás - Goiás. For this, the following specific objectives were established for this work: a) enumerate the participation in continuing education of teachers from the School Unit of the State Public Education Network during the years 2018 and 2019; b) identify the situation of the teacher's workload at the school and its relationship with continuing education; c) verify the participation of teachers in training of teachers in continuing education offered by other institutions. With regard to methodological procedures, this is an exploratory field research with a quantitative approach, carried out with 24 teachers. The data collected through a questionnaire were systematized and analyzed according to a quantitative approach, which allowed us to consider that continuing education is a challenge because it depends on factors related to the teacher, such as intense routine with high workload, lack of salary appreciation and Social; and, elements external to the teacher such as the lack of continuing education offered by the State Department of Education.
\end{abstract}

Keywords: Continuing education; Teaching; Pedagogical practices.

\section{Resumen}

Este trabajo tiene como objetivo conocer las principales interferencias en la formación continua de los docentes desde las percepciones de los docentes de la Unidad Docente de la Red Pública Estatal en la ciudad de Santa Helena de Goiás - Goiás. Para ello, se establecieron los siguientes objetivos específicos para este trabajo: a) enumerar la 
participación en la formación continua de los docentes de la Unidad Escolar de la Red de Educación Pública del Estado durante los años 2018 y 2019; b) identificar la situación de la carga de trabajo del docente en la escuela y su relación con la educación continua; c) verificar la participación de los docentes en la formación de docentes en la educación continua ofrecida por otras instituciones. En cuanto a los procedimientos metodológicos, se trata de una investigación de campo exploratoria con enfoque cuantitativo, realizada con 24 docentes. Los datos recolectados a través de un cuestionario fueron sistematizados y analizados de acuerdo con un enfoque cuantitativo, lo que permitió considerar que la educación continua es un desafío ya que depende de factores relacionados con el docente, como la rutina intensa con alta carga de trabajo, la falta de apreciación salarial y social; y, elementos externos al docente, como la falta de educación continua que ofrece el Departamento de Educación del Estado.

Palabras clave: Educación continua; Enseñando; Prácticas pedagógicas.

\section{Introdução}

Os desafios cotidianos em sala de aula, como ensinar, acompanhar e avaliar, exige do professor uma formação contínua e práticas pedagógicas inovadoras, diante de um mundo globalizado em que tecnologias avançadas surgem a cada momento. O compromisso do professor em atualizar-se é urgente e necessário, proporcionando a transformação da informação do senso comum em uma abordagem científica. O professor não é mais um transmissor de conhecimentos, seu papel é amplo e complexo. Para isso, a formação continuada deve ser concreta e contínua.

A formação de professores e suas práticas pedagógicas é um tema que tem instigado muitos autores: Nóvoa (1999), Tardif (2002), Freire (1979) e outros, aguçando assim, o nosso interesse em estudar os eventuais motivos da interferência ou contribuição para as práticas pedagógicas em sala de aula.

Os nossos sujeitos de estudo foram os professores de um Colégio do município de Santa Helena de Goiás. Esta investigação deu-se pelo fato do Colégio localizar-se em uma área que abrange os bairros mais vulneráveis do município de Santa Helena de Goiás, pois acredita-se os profissionais participam de formações continuadas, suas aulas são melhores, podendo ainda ajudar seus alunos em outros aspectos, não somente o escolar.

Neste contexto, a pesquisa justifica-se pela importância de conhecer as principais interferências na formação continuada dos professores, refletindo em suas práticas pedagógicas em sala de aula, a partir das percepções dos professores da Unidade de Ensino da Rede Pública Estadual do município de Santa Helena de Goiás. Já a relevância social deste estudo é possibilitar à reflexão dos profissionais da educação, da importância da formação continuada.

Diante disso, surge então a pergunta norteadora deste estudo: Quais motivos interferem a formação continuada docente a partir das percepções dos professores da Unidade de Ensino da Rede Pública Estadual do município de Santa Helena de Goiás - Goiás?

Diante da problemática apresentada, esta pesquisa objetiva conhecer as principais interferências na formação continuada dos professores a partir das percepções dos professores da Unidade de Ensino da Rede Pública Estadual do município de Santa Helena de Goiás - Goiás. Para isso foram estabelecidos os seguintes objetivos específicos para este trabalho: a) enumerar as participações em formações continuadas dos professores da Unidade Escolar da Rede de Ensino Público Estadual durante os anos de 2018 e 2019; b) identificar a situação da carga horária do docente na escola e a sua relação com a formação continuada; c) verificar a participação dos docentes em formação dos docentes em formação continuada oferecida por outras instituições.

\section{Referencial Teórico}

\subsection{0 contexto escolar}

Ao tratarmos da formação continuada, pensemos na escola como uma instituição que acolhe o docente para a realização da sua práxis. Para isso, sua formação continuada contribuirá para aulas mais dinâmicas e que atendam à clientela que cada dia mais é exigente. 
Para Capucho (2012) a alta rotatividade de professores (as) nas escolas, a fragilidade da formação inicial e continuada, excesso de estudantes em sala de aula, baixos salários e desigualdades sociais, acessibilidade, adaptação de materiais didáticos e pedagógicos, são alguns elementos que devem ser analisados para uma efetivação de práticas pedagógicas concretas na formação de professores, levando-se em conta que por muitas vezes têm sua docência constituída na improvisação e no aligeiramento.

Para Figueiredo (2002) a formação de professores é comparada a nós seres humanos, seres inacabados e em constante transformação, pois ora acertamos, ora erramos. A formação continuada exige do professor a reflexão que também é aprendente, transformando sua prática pedagógica e respeitando toda esta diversidade na gestão de sala de aula.

\subsection{Docência}

A educação de qualidade em perspectiva emancipatória, com vistas a formar professores e alunos como sujeitos investidos de autonomia se encontra comprometida. e é nesse sentido que resgatamos o conceito de autonomia em Freire (1996) como princípio pedagógico para uma educação libertadora, onde está propicie as necessárias condições à professores educandos no desenvolvimento de sua subjetividade, a partir de sua visão do mundo.

$\mathrm{Na}$ atual contemporaneidade não se concebe mais, como no pensamento Freireano uma educação bancária em que o professor deposita os conhecimentos como se a cabeça do estudante fosse uma caixa arquivadora onde não há reciprocidade do saber, tolindo a mente de pensar e ter criticidade sobre o que ouve, lê ou estuda.

O professor precisa conscientizar-se de que o conhecimento científico é necessário para sua prática pedagógica em sala de aula. esta tarefa é árdua e complexa, pois seu saber recebe influência das relações sociais, culturais, econômicas e políticas. cabe ao docente desenvolver e ampliar a atividade intelectual do aluno.

Gimeno Sacristán (1999) evidencia o ato educativo do professor e sua intencionalidade:

[...] a educação não é algo espontâneo na natureza, não é mera aprendizagem natural, que se nutre dos materiais culturais que nos rodeiam, mas uma intervenção dirigida, uma construção humana que tem sentido e que leva consigo uma seleção de possibilidades, de conteúdos, de caminhos.

$\mathrm{Na}$ sala de aula, o professor ensina e aprende, demonstrando habilidades e competências, expondo conhecimentos acumulados. Todo conhecimento adquirido pelo professor, suas vivências, contribuirão para o ensino do aluno.

Os saberes docentes são construídos no campo de produção simbólica adquiridos através de vivências, embates teóricos e oportunidades de leitura de mundo que os professores têm em seu campo de atuação.

\subsection{Formação docente}

A docência é um processo dinâmico e complexo, caracterizado pela dinamicidade da sala de aula que recebe um número expressivo de estudantes com diversidade social e cultural.

Nóvoa (1999) defende que a formação docente é um processo interativo que une a prática a discussões teóricas, gerando novos conceitos. É um processo lento, percebendo que os saberes docentes plurais e complexos e o professor é o sujeito e a escola: espaço de formação em serviço.

É necessária e urgente uma formação inicial ou continuada, com base teórica, relacionando teoria e prática, gerando uma práxis educativa, ou seja, um conhecimento científico, frente às mudanças rápidas da sociedade, às quais o aluno está inserido.

Tozetto (2013) comenta que o professor necessita de estudo permanente e coerente ao exercer sua prática pedagógica em sala de aula. Nóvoa (1999) defende uma formação continuada, não mais como reciclagem, mas uma qualificação para as 
novas funções da escola e do professor, onde o professor e a instituição escolar a qual está inserido, ganham em conhecimento e mudanças nas práticas educativas, gerando uma conversa consigo mesmo, sua prática e suas concepções teóricas.

Quando não há uma formação continuada para articular teoria e prática, não é possível se ter um docente atuante na instituição escolar com qualidade, embora não há de se esquecer que a formação continuada é um processo a ser desenvolvido pelo professor em toda sua carreira. Este desenvolvimento profissional pode ser entendido como "uma atitude permanente de indagação, de formulação de questões e procura de soluções" (Marcelo, 2009).

Para Tardif (2002) atualmente a educação se insere em um ambiente complexo, a inclusão de grupos antes marginalizados tenciona este ambiente. Não há mais lugar para as velhas práticas pedagógicas. Neste contexto de mudanças, o papel do professor destaca-se como catalisador dessas inovações. O professor recebeu uma formação pautada no paradigma técnico e científico para trabalhar com grupos homogêneos, no entanto hoje enfrenta grupos heterogêneos exigindo-lhe que desenvolva em seus alunos a capacidade de trabalhar em grupo, resolver problemas, etc.

Para Almeida (2000) o professor é um eterno aprendiz realizando uma "leitura" em uma reflexão sobre sua prática pedagógica, sendo o mediador da aprendizagem de seus alunos. A formação de professores tem sido revista, discutida e analisada por pesquisadores desta área.

Para Antunes (2013) consciência de que jamais cessa o tempo de aprender. Sempre se acredita em processo de formação e que a qualidade profissional não se conquista senão pelo estudo permanente, dedicação extremada e atenção em, a cada dia, aprender novas ferramentas para a gestão da sala de aula.

\subsection{Formação continuada e seus Instrumentos Legais}

A formação continuada para o docente é necessária e urgente, pois quem não se atualiza não consegue acompanhar as informações que surgem a todo instante, novas propostas do ensino, atualização da legislação educacional e o ensino de nove anos, compreendendo: a Educação Infantil para crianças de zero a cinco anos de idade; Ensino Fundamental- anos iniciais compreendendo do $1^{\circ}$ ao $5^{\circ}$ ano e Ensino Fundamental -anos finais- período formado pelo $6^{\circ}$ ao $9^{\circ}$ ano, implicando muito preparo, conhecimento e disponibilidade do educador para às novas situações vividas na sala de aula.

A atividade educacional está atrelada à função social da escola. Segundo Wittmann citado por Moreira (2002, p. 14) "as competências docentes, hoje, demandam um processo continuado/qualificação ou contínua (re) construção".

Para Feldmann (2003) formar professores com qualidade social e compromisso político de transformação, é um desafio atualmente. Formar professores é defrontar-se com a instabilidade e provisoriedade do conhecimento, não esquecendo das políticas públicas que não valorizam o professor como um ser provido de saberes.

Que o mundo muda sem cessar: eis aí certamente uma banalidade. Mas para aqueles que analisam o mundo atual, alguma coisa de radicalmente nova surgiu, alguma coisa mudou na própria mudança: é a rapidez e a aceleração perpétua de seu ritmo, e é também o fato de que ela se tenha tornado um valor enquanto tal, e talvez o valor supremo, o próprio princípio da avaliação de todas as coisas (Forquin, 1993, p.18).

Formar professores é trabalhar em uma situação muito particular, deste docente onde passou por instituições cujo modelo de formação está baseado na racionalidade tecnocrática.

Segundo Nóvoa (1992, p. 24), “... a formação de professores tem ignorado, sistematicamente, o desenvolvimento pessoal, confundindo formar e formar-se, não compreendendo que a lógica da atividade educativa nem sempre coincide com as dinâmicas próprias da formação". 
A formação continuada deve também ser discutida a partir da análise das Metas 15 e 16 do Plano Nacional de Educação-PNE 2014-2024, anexo à Lei 13005/14; a LDB- Lei 9.394; Diretrizes Curriculares nacionais para a Formação de Professores da Educação Básica e a Rede Nacional de Formação Continuada de Professores.

A LDB, Lei no 9.394/96 exige a formação continuada dos professores. É necessário conhecer as leis que ditam seus direitos e deveres para exigir das autoridades competentes que as mesmas sejam cumpridas.

Em relação aos direitos, recorremos à Lei de Diretrizes e Bases da Educação Nacional- Lei n 9.394/96, no Artigo 13, que destaca:

Os docentes incumbir-se-ão de:

I. participar da elaboração da proposta pedagógica do estabelecimento de ensino;

II. elaborar e cumprir plano de trabalho, segundo a proposta pedagógica do estabelecimento de ensino;

III. zelar pela aprendizagem dos alunos;

IV. estabelecer estratégias de recuperação para os alunos de menor rendimento;

V. ministrar os dias letivos e horas-aula estabelecidos, além de participar integralmente dos períodos dedicados ao planejamento, à avaliação e ao desenvolvimento profissional;

VI. colaborar com as atividades de articulação da escola com as famílias e a comunidade (Brasil, 1996, p. 16).

Segundo a LDB, o professor é extremamente relevante para que a qualidade do ensino seja cumprida e aperfeiçoada diariamente. O professor sofre cobranças diuturnamente de todos os lados, mas não pode deixar que a qualidade do ensino sofra com isso, sua luta continuará sempre para estabelecer como um profissional de qualidade e capaz.

A formação continuada é uma das formas de valorização do profissional. Sobre esse assunto a LDB esclarece:

Art.67. Os sistemas de ensino promoverão a valorização dos profissionais da educação, assegurando-lhes, inclusive nos termos dos estatutos e dos planos de carreira do magistério público:

I. ingresso exclusivamente por concurso público de provas e títulos;

II. aperfeiçoamento profissional continuado, inclusive com licenciamento periódico remunerado para esse fim;

III. piso salarial profissional;

IV.progressão funcional baseada na titulação ou habilitação, e na avaliação do desempenho;

V. período reservado a estudos, planejamento e avaliação, incluído na carga de trabalho;

VI. condições adequadas de trabalho (Brasil, 1996, p. 21).

A Lei garante a formação continuada aos professores, mas para que seja cumprida, basta que a categoria se fortaleça, para que se possa lutar por esse ideal. Por isso, o professor não pode desistir nunca, pois ser professor enobrece o cidadão, a escolha dessa profissão deve trazer respeito, sabedoria e humildade para sua valorização.

As Diretrizes Curriculares Nacionais para a formação de Professores da Educação Básica estabelecem um novo perfil docente, centrado no desenvolvimento de competências:

[...] evidencia a necessidade de que o futuro professor experiencie, como aluno, durante todo o processo de formação, as atitudes, modelos didáticos, capacidades e modos de organização que se pretende venham a ser concretizados nas suas práticas pedagógicas [...] (Brasil, 2001, p.30-31).

O PNE 2014-2024, com foco nas metas 15 e 16 trata da questão da formação inicial e continuada de professores:

Garantir, em regime de colaboração entre a União, os Estados, o Distrito Federal e os Municípios, no prazo de 1 ano de vigência deste PNE, política nacional de formação dos profissionais da educação de que tratam os incisos I, II e III do caput do art. 61 da Lei $\mathrm{n}^{\circ}$ 9.394, de 20 de dezembro de 1996, assegurado que todos os professores e as professoras da educação básica possuam formação específica de nível superior, obtida em curso de licenciatura na área de conhecimento em que atuam (Brasil, 2014). 
Essas metas propõem diversas ações, legislando sobre os modelos de formação inicial e continuada, a valorização da carreira do magistério (Piccinini et al., 2014, p. 1586). O MEC traz outras disposições conferindo ênfase à formação continuada:

1. em outros Artigos da LDB: Art. 63, manutenção de "[...] programas de educação continuada para os profissionais de educação dos diversos níveis [...]"; Art. 67 "[...] promoção da valorização dos profissionais da educação [...] aperfeiçoamento profissional continuado [...]" e, o Art. 80, que abre caminho para que o ensino a distância também seja um caminho para a formação continuada;

2. no Parecer $n^{\circ}$ CNE/CP 009/2001 (BRASIL, 2001), que fundamenta as Diretrizes, a formação continuada aparece como atendimento "[...] a formação (que) deva ser complementada ao longo da vida [...]" (p.9); ao endossar os artigos da LDB que fazem referência à "relação entre teoria e prática" e no "aproveitamento da experiência anterior", ao construir aprendizagens significativas junto aos futuros alunos; e, oferta de "programas de educação continuada" (p.14). Ao finalizar traz que "É ainda no momento de definição da estrutura institucional e curricular do curso que caberá a concepção de um sistema de oferta de formação continuada que propicie oportunidade de retorno planejado e sistemático dos professores às agências formadoras [...]" (p.58);

3. nas Metas 1, 3, 4, 5, 7, 10 onde a formação continuada está presente quer promovendo a formação, incentivando práticas pedagógicas estruturadas a partir da relação teoria/prática, quer repensando currículos, ampliação de vagas e outros.

A Rede Nacional de Formação Continuada de professores (Brasil, 2004), “[...] criada em 2004, com o objetivo de contribuir para a melhoria da formação dos professores e alunos. Opúblico-alvo prioritário da Rede são professores de Educação Básica dossistemas públicos de educação [...]”".

Segundo o Catálogo de Orientações Gerais da Rede Nacional de Formação Continuada:

A formação continuada não pode ser reduzida à atualização, menos ainda a um treinamento ou capacitação para a introdução de inovações ou compensação de deficiências da formação inicial. Devido a experiências anteriores, é comum entre os professores considerar programas institucionais como pacotes a serem executados, gerando uma atitude refratária a eles e comprometendo propostas de formação continuada (MEC/Brasil, 2006, p. 24).

\subsection{A prática pedagógica do professor}

É relevante compreender as implicações da formação continuada na prática reflexiva do professor, onde essa prática é construída no exercício da docência quando se disponibiliza para mudar uma realidade. Para Barbosa e Fernandes (2018), a teoria do professor reflexivo vai ao encontro da formação continuada, por ser um momento em que a prática do professor está no centro, a ação e o conhecimento prático são o foco dessa formação.

Esses mesmos autores destacam que a proposta que Shön sugere que a formação profissional deve ter como base a epistemologia da prática: com a valorização da construção de conhecimento no momento da prática profissional, por meio da reflexão, análise e problematização da prática, na prática.

Schön (1987) também elaborou uma teoria do professor reflexivo, interligando com a a formação continuada por possuir elementos relevantes que fortalecem o processo de aprendizagem e o desenvolvimento do professor no cotidiano da sala de aula.

A teoria de Shön no Brasil iniciou a partir das obras de Antônio Nóvoa e Maurice Tardif pelo próprio Schön, em que apresentam suas concepções e contribuições para os saberes da docência e na formação profissional dos professores.

Segundo Imbernón (2001, p. 48-49), "a formação terá como base uma reflexão dos sujeitos sobre sua prática docente, realizando um processo constante de autoavaliação que oriente seu trabalho".

Esta visão permite ao docente olhar para si buscando compreender suas atitudes e ações, estimulando a fazer uma análise e problematizar suas experiências de maneira centrada. 
A prática como fonte geradora de conhecimento vem sendo estudada por muitos estudiosos, tentando esclarecer as competências e habilidades necessárias para que o professor desempenhe seu trabalho nos dias atuais. A prática pedagógica é uma atividade humana constituída em atividade prática, utilitarista, ativista e espontaneísta ou em umas práxis guiadas por intenções conscientes.

A prática pedagógica reflexiva é aquela enunciada por Freire (1975, p. 9), "ninguém educa ninguém, como tampouco ninguém se educa a si mesmo: os homens se educam em comunhão, mediatizados pelo mundo". É a indissolubilidade entre teoria e prática. A vida na escola, na sala de aula, tem de ser muito mais do que a transmissão de um conteúdo sistematizado do saber. É necessário que o professor compreenda os anseios das novas gerações e perscrutar os rumos do futuro.

A prática pedagógica do professor não é neutra nem deve ser burocrática, esta ação deve ser definida filosófica e socialmente. $\mathrm{O}$ processo de formação do professor é inseparável da prática e da reflexão na e sobre a prática. O professor reflexivo é inquieto e insatisfeito e que em sua luta diuturna, persegue a autonomia.

Um projeto histórico construído cotidiana e coletivamente traduz-se para o professor em um projeto pedagógico, projeto implícito, presente em sua consciência, é o guia de suas ações. Seu trabalho deve ser pautado em uma concepção teórica, onde esteja presente sua opção por uma teoria de conhecimento.

"Os professores reflexivos estão sempre se questionando sobre o seu saber, sobre o seu fazer e sobre o seu saber fazer em sala de aula, indo além das atitudes imediatistas, tendo presente o tipo de homem que se quer formar" (Ribas; Carvalho, 1995, p. 4)

Uma nova competência pedagógica nasce na reflexão sobre a própria prática, no movimento dialético ação-reflexãoação.

Tanto a teoria quanto a prática têm papel assegurado neste processo, porque as teorias são como mapas que nos ajudam a viajar sobre o momento presente para auscultar a realidade, o que não se faz sem a história. O que se busca na verdade, é a construção de uma prática pedagógica reflexiva, crítica e criativa (Schimidt; Ribas; Carvalho, 1995, p. $5)$.

O professor reflexivo está sempre atento à possibilidade de mudanças, ele é inquieto, insatisfeito, persistente, um ser inacabado ousando experimentar o novo, exercitando sua prática pedagógica no âmbito escolar, sua autonomia. O professor é responsável pelo seu próprio desenvolvimento, ficando com todo possível ônus dessa busca de aperfeiçoamento e tentativa de mudança.

A prática pedagógica reflexiva no âmbito escolar, é a busca constante de dados da realidade em que o professor está inserido, isto é, os dados da prática, do saber, da experiência, sem perder os vínculos com a realidade social global, para, pela ação-reflexão-ação, compreendê-la e modifica-la, tendo em vista os fins educativos estabelecidos coletivamente no projeto político-pedagógico da escola (Ribas; Carvalho, 1995, p. 6).

\section{Metodologia}

A presente pesquisa está pautada na abordagem quantitativa, com caráter exploratório, segundo Gil (2002, p. 42), desenvolvida com professores com faixa etária de 18 a 61 anos, em um Colégio Estadual do município de Santa Helena de Goiás-Goiás, onde ministram aulas no Ensino Fundamental- anos finais, para alunos de $6^{\circ}$ ao $9^{\circ}$ ano. Como instrumento de coleta de dados foi utilizado um questionário com 19 questões fechadas e com múltipla escolha.

O roteiro das questões continha uma primeira parte referente ao perfil do sujeito (estado civil, formação acadêmica e âmbitos de trabalho) e em seguida, perguntas norteadoras do questionário. 
No que se refere aos procedimentos metodológicos do estudo, trata-se de uma pesquisa de campo de caráter exploratório com abordagem quantitativa, desenvolvida com professores e professoras com faixa etária de 18 a 61 anos, em um Colégio Estadual do município de Santa Helena de Goiás-Goiás. Como instrumento de coleta de dados foi utilizado um questionário com questões abertas e com múltipla escolha.

Para iniciar a investigação, primeiramente foi necessário estabelecer contato com a Gestora da Unidade da Unidade Escolar do município de Santa Helena de Goiás-Goiás para obter autorização para realização da pesquisa. Após obter o consentimento da Gestora, foram encaminhados os Termos de Consentimentos Livres e Esclarecidos (TCLE). Com isso, foi possível fazer alguns levantamentos relacionados à caracterização da área, assim como da população público-alvo da pesquisa.

Para delimitar o universo desta pesquisa, foi realizado um levantamento das escolas estaduais de Santa Helena de Goiás-Goiás: Escola Estadual "Serafim Azevedo"; Colégio Estadual "Vital de Oliveira”; Colégio Estadual "José Salviano Azevedo"; Escola Estadual "Rafael Nascimento"; Colégio Estadual “Avelino Martins Rodrigues”; Escola Estadual "Djalma de Freitas". Ressalta-se que a escolha da unidade escolar se deu em razão do Colégio localizar-se em uma área que abrange os bairros mais vulneráveis do município de Santa Helena de Goiás-Goiás e ainda porque os participantes da pesquisa que ali trabalham, se encaixarem no perfil do público-alvo do estudo.

O Colégio selecionado durante os anos de 2018 e 2019 teve uma considerável rotatividade de professores contratados pela SEDUCE - Secretaria do Estado da Educação de Goiás, dificultando assim o andamento da pesquisa.

A pesquisa relacionada à formação continuada dos professores de uma Unidade Escolar do município de Santa Helena de Goiás-GO iniciou-se em setembro de 2019, por meio da escolha do tema e da escrita do projeto. No período de outubro de 2019 a novembro de 2020 foram realizados estudos bibliográficos com a finalidade de ampliar os conhecimentos inerentes ao assunto abordado nesta pesquisa.

Após a obtenção do consentimento dos participantes da pesquisa, no dia 01/12/2020, a pesquisadora dirigiu-se ao Colégio, objeto da pesquisa, onde estava sendo realizada uma reunião com todos os professores para traçar as metas para o ano de 2021 e fechamento do ano letivo de 2020. Por tratar-se de fechamento/organização de notas, diante de um cenário pandêmico e proliferação no novo coronavírus (SARS-COV-2-COVID 19), os questionários foram entregues aos sujeitos da pesquisa no mês de dezembro de 2020. Os questionários não foram respondidos on-line com as plataformas próprias, devido à falta de experiência e desconhecimentos dos participantes em manuseá-las. Vale destacar que em razão do novo coronavírus, os participantes levaram os questionários para serem preenchidos em suas residências, tomando medidas de biossegurança: uso do álcool gel 70\%, uso de máscara e questionário envelopado.

A partir da entrega, os questionários foram tabulados e logo depois analisados.

\section{Resultados e Discussão}

A formação continuada de professores é uma forma de assegurar a atuação de profissionais mais preparados e capacitados dentro das salas de aula. Dessa forma, ela garante uma educação de qualidade para seus alunos e, consequentemente, a comunidade na qual a escola está inserida. Uma formação de professores adequada serve como alicerce para construir escolas e profissionais mais competentes, éticos e humanos.

Através da pesquisa, verifica-se a atuação no magistério na Unidade Escolar pesquisada, em sua maioria é composta por docentes do sexo feminino, representando mais de $95 \%$, enquanto do sexo masculino representam apenas 4,16\%.

Desde o século XIX, onde o Brasil era hegemonicamente agrário, a educação feminina era restrita aos cuidados com a casa, o marido e os filhos, revelando um paternalismo que teve como impactos, dentre outros, levar a mulher à condição de mera reprodutora, afastando-a da educação formal, não sendo permitido acesso à escola. (Louro, 1997, p.77) 
A docência tomou a condição de eminentemente espaço feminino, no século XX, revelando-se uma atividade profissional com presença feminina:

[...] Nas creches, na pré-escola e nos anos iniciais do ensino fundamental, o universo docente é predominantemente feminino $(98 \%, 96 \%$ e $91 \%$, respectivamente). No entanto, a cada etapa do ensino regular amplia-se a participação dos homens, que representam 8,8\% nos anos iniciais do ensino fundamental, 25,6\% nos anos finais e chegam a 35,6\% no ensino médio. (...) Não obstante, se consideradas todas as etapas e modalidades da educação básica, $81,6 \%$ dos professores que estavam em regência de classe são mulheres e somam mais de um milhão e meio de docentes 1.542.925. (INEP - Censo do Professor, 2007).

Compreender como ocorreu a feminização da docência é ter a leitura de que tal processo não se refere somente à presença de mulheres, mas especialmente à associação da escola a símbolos da feminilidade. Contar com a participação de mulheres o de homens na atividade de professoras e professores é pensar em uma pequena parte das dimensões simbólicas da realidade educacional.

É importante a compreensão de que tanto as feminilidades quanto as masculinidades são historicamente construídas, "gênero se constitui em cada ato da nossa vida, seja no plano das ideias, seja no plano das ações. O tempo inteiro a gente está constituindo o gênero no nosso próprio cotidiano". (Grossi, 2004, p. 09).

No Gráfico 1, mostra que na Unidade Escolar pesquisada temos uma predominância de professores entre as faixas etárias de 21 a 45 anos, sendo que 37,5\% estão entre 36 e 45 anos; 33,33\% entre 21 e 35 anos; 20,83\% entre 46 e 55 anos; $4,16 \%$ acima de 55 anos e $4,16 \%$ até 20 anos.

Gráfico 1: Idade.

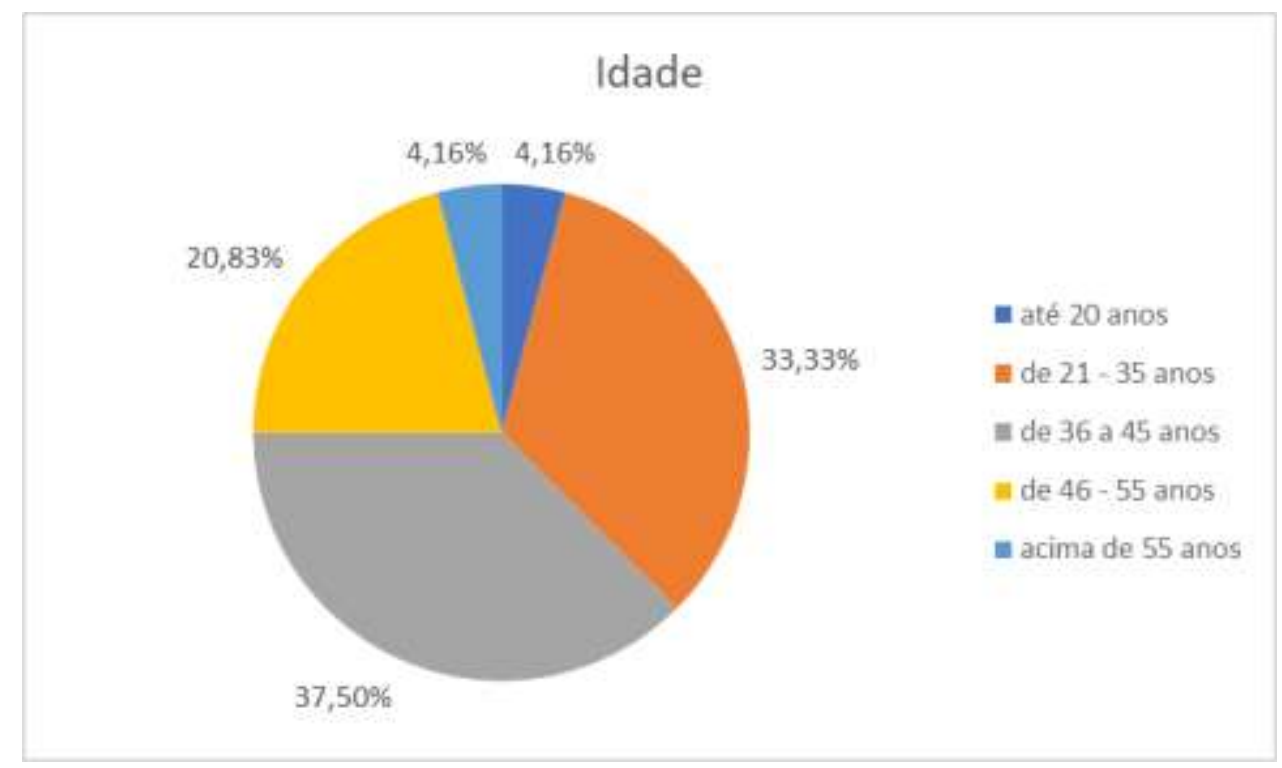

Fonte: Dados da Pesquisa (2020).

Quanto a idade dos docentes que responderam ao questionário, isso pode corroborar com a afirmação de Polena e Gouveia (2013), de que os profissionais docentes estão envelhecendo. Em uma sociedade em acelerada transformação, a necessidade de professores capacitados para transmitir os conhecimentos necessários às novas gerações é inquestionável. A busca de conhecimento se acentua a cada dia, gestores de educação, percebem seus quadros de professores envelhecendo e a qualidade de jovens interessados na profissão diminuindo de modo ainda mais rápido. 
Alguns pesquisadores como Huberman (1989), Seffy (1989), Nóvoa (1995), Cavaco (1995), durante vários anos vêm pesquisando e pela primeira vez, empiricamente, desenharam-se as trajetórias profissionais docentes completas, onde os resultados indicaram o período de entrada na carreira como um momento de sobrevivência (choque do real: a confrontação com a complexidade da situação profissional) e de descobrimento (entusiasmo inicial por inserir-se numa categoria profisssional. A fase seguinte, de estabilização, significa o comprometimento definitivo. Nas subsequentes, os percursos individuais pareciam diferenciar-se, conduzindo à diversificação (experimentação de novas estratégias didáticas, sem o receio de se contrapor às pressões institucionais) e/ou a um questionamento (balanço da vida profissional, com a avaliação da possibilidade de abraçar uma outra profissão). As fases de serenidade tranquilidade e sentimento de domínio da situação pedagógica) ou do conservantismo (lamentações e resistência às inovações, ou seja, participar de formação continuada). Finalmente o desinvestimento amargo (se impregnado de lamentações), ou sereno (com tranquilidade e investimentos em projetos próprios).

No Gráfico 2, mostra o nível socioeconômico do docente da escola pesquisada, onde muitos são professores contratados, recebendo apenas um salário abaixo do piso salarial, dificultando assim, sua sobrevivência e recursos para participar de cursos de formação continuada.

Gráfico 2: Nível socioeconômico do docente.

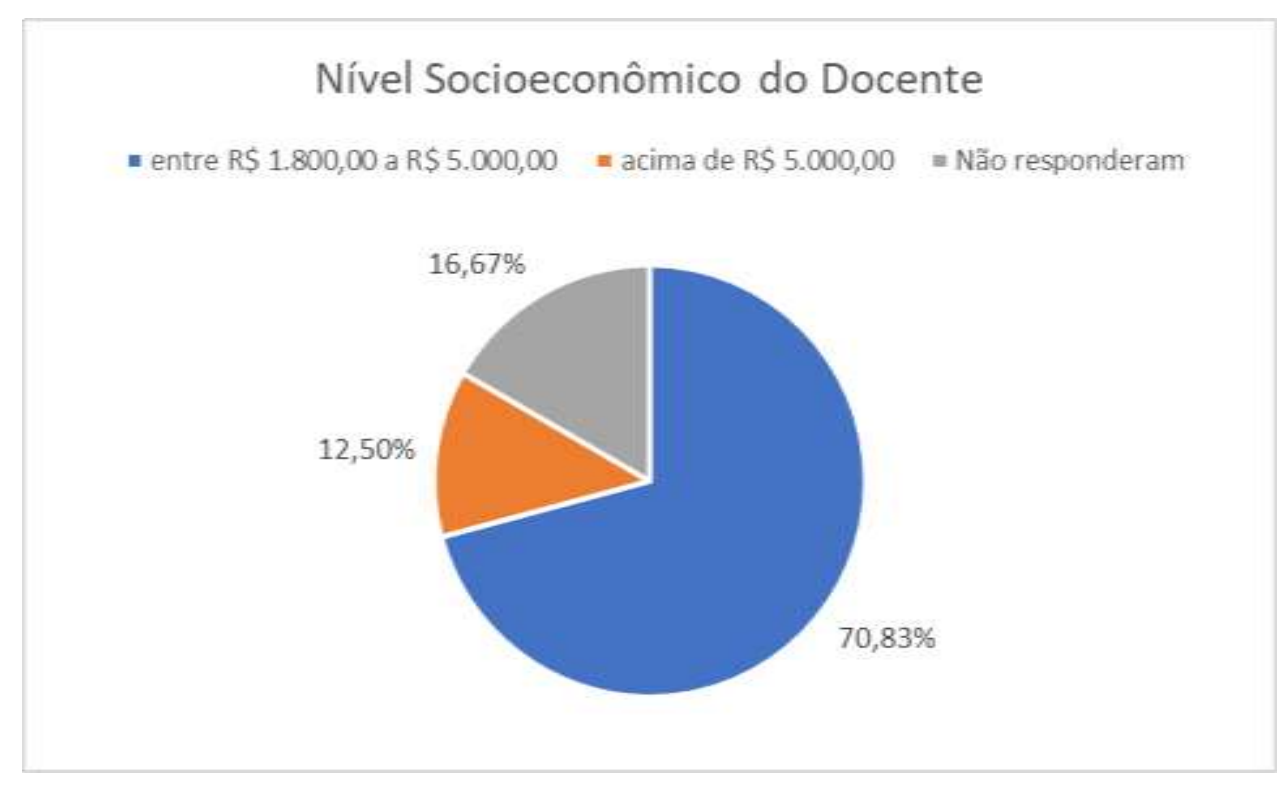

Fonte: Dados da Pesquisa (2020).

Quanto a renda dos docentes entrevistados, podemos observar no Gráfico 2, que 70,83\% recebem entre $\mathrm{R} \$ 1.800,00$ a $5.000,00,12,50 \%$ recebem acima de $\mathrm{R} \$ 5.000,00$ e 16,6\% não responderam a esta pergunta. Observamos ainda que muitos professores não recebem o piso salarial nacional dos profissionais da rede pública da educação básica no início de carreira que é o valor de $\mathrm{R} \$ 2.886,24^{1}$, de acordo com a Lei $\mathrm{n}^{\circ} 11.738$ de 16/07/2008, ressalta-se que o último concurso realizado foi somente de títulos e para professores de Biologia, Física, Química e Matemática. As outras áreas não foram contempladas.

No Gráfico 3, verifica-se que $83,34 \%$ dos professores alvo desta pesquisa possuem formação inicial para a docêncialicenciatura e 8,34\% não possuem habilitação acadêmica. O conhecimento especializado adquirido em um curso de ensino superior é um diferencial, tanto para o crescimento profissional, como para o pessoal, ou seja, professores com formação específica, suas aulas tendem a ser melhores.

\footnotetext{
${ }^{1}$ http://portal.mec.gov.br/component/tags/tag/piso-salarial
} 
Gráfico 3: Formação inicial para a docência- Licenciatura.

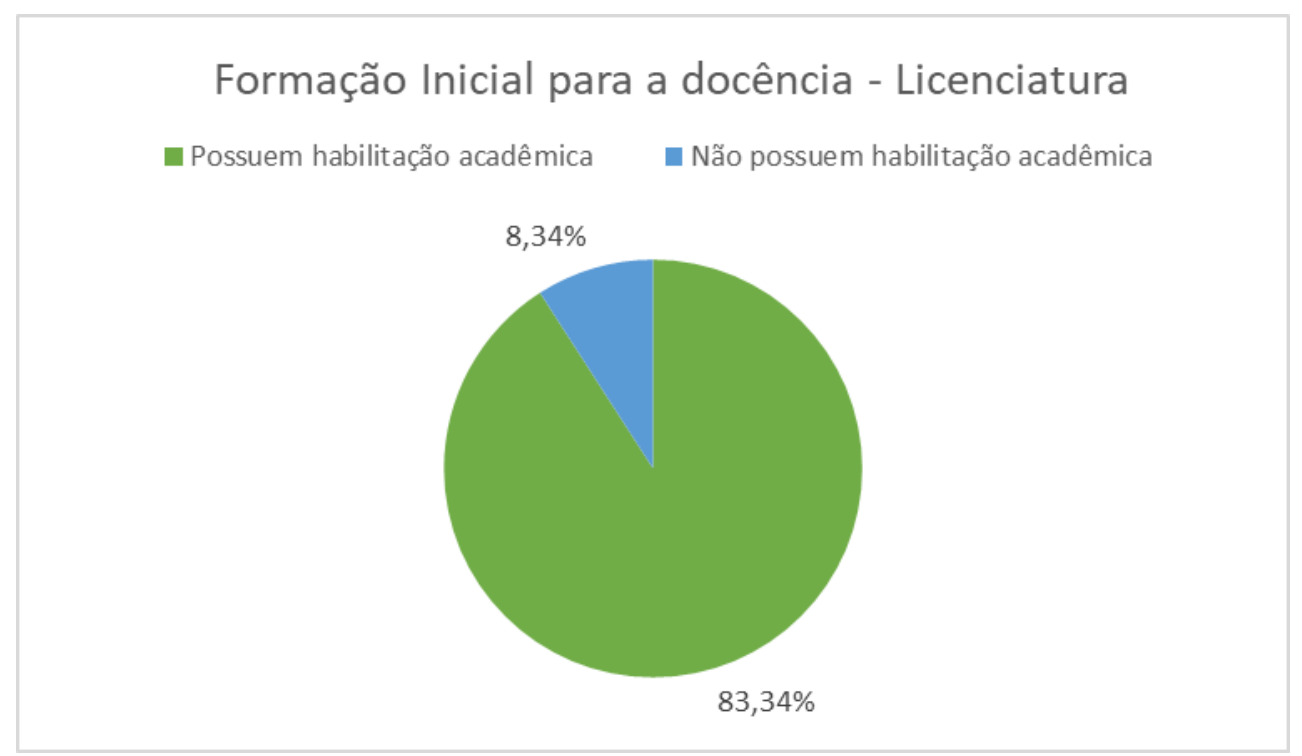

Fonte: Dados da Pesquisa (2020).

A construção da docência é um processo contínuo e inacabado, é fundamental que os profissionais que atuam na área da educação estejam inseridos em cursos de formação. Trazer em foco a formação continuada é bastante significativo, pois esse processo está interligado diretamente com a melhoria das práticas pedagógicas e com a profissionalização docente.

No Gráfico 4, percebe-se que 79,16\% dos docentes não cursaram nenhuma pós-graduação e nem ressaltaram os motivos e que apenas 20,84\% dos docentes fizeram alguma pós-graduação.

Gráfico 4: Habilitação acadêmica - Pós-graduação.

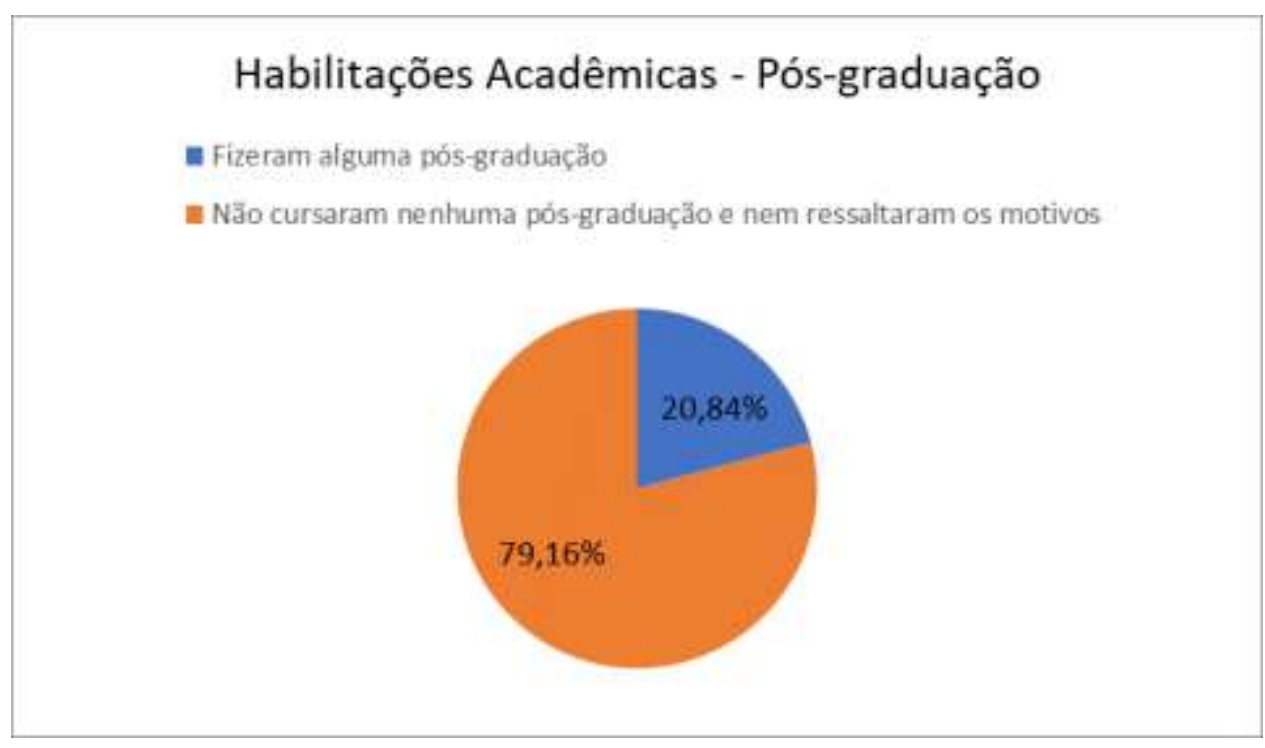

Fonte: Dados da Pesquisa (2020).

Para Tardif (2012) exige-se competência pedagógica e bom desempenho em sala de aula para atender às expectativas dos alunos.

Em nossa região há o oferecimento de cursos de formação continuada para os professores, oferecidos de forma pública e gratuita com as especializações lato sensu e stricto sensu oferecidas pela Universidade Federal de Jataí (UFJ), 
Instituto Federal Goiano (IF Goiano), Instituto Federal de Goiás (IF Goiás), Universidade Estadual de Goiás (UEG), além de Faculdades e Universidades privadas e municipais. Na Universidade de Jataí- Goiás ${ }^{2}$ oferece pós-graduação strictu sensu em diversas áreas: Educação, Geografia, Química e o Mestrado Profissionalizante em matemática em rede-PROFMAT, tudo oferecido gratuitamente para a formação contínua do docente.

No Instituto Federal de Educação, Ciência e Tecnologia Goiano- IF Goiano, campus Rio Verde-Goiás, há a oferta da Especialização Formação de Professores e Práticas Educativas³. Há cursos de formação contínua oferecidos gratuitamente, basta que o docente tenha a iniciativa de cursá-los.

Já os dados do Gráfico 5, demonstram 58,34\% dos professores são contratados e 41, 67\% são professores regentes que prestaram o concurso público Estadual.

Gráfico 5: Estatuto Profissional.

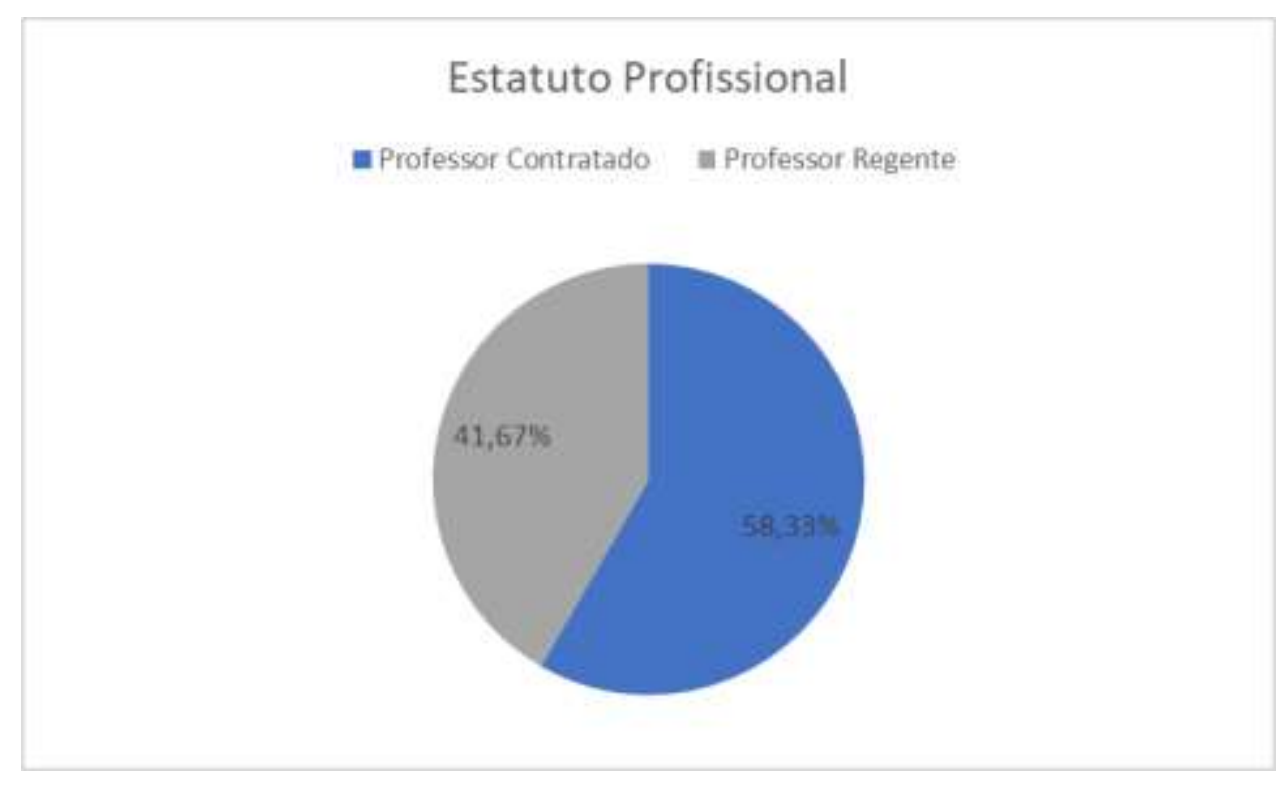

Fonte: Dados da Pesquisa (2020).

A Lei $n^{\circ} 13.664$ de 27 de julho de 2000, Lei que rege os Contratos Temporários em Goiás, foi revogada pela Lei ${ }^{\circ}$ 20.918 de 21 de Dezembro de 2020 que estendeu o prazo de trabalho dos Contratos Temporários ${ }^{4}$ que pode estender-se até 05 anos, dependendo da necessidade da Unidade Escolar.

Para Novaes (2010) a contratação dos professores revela uma das faces da precarização do trabalho docente no Brasil, fazendo com que a Unidade Escolar perca com a rotatividade destes profissionais, onde são privados da possibilidade de planejar em longo prazo suas relações didático-pedagógicas, alheados da escolha de recursos e materiais ou, mesmo de planejamento.

No Gráfico 6, verifica-se que 25\% exercem a função de Magistério até 1 ano; 20,84\% exercem a função de Magistério de 02 a 10 anos: 20,84\% exercem a função de magistério de 11 a 20 anos; 20,83\% exercem a função de Magistério de 21 a 30 anos e 12,5\% não responderam o tempo que exercem a função de Magistério.

\footnotetext{
2 https://copg.jatai.ufg.br/.

${ }^{3}$ https://www.ifgoiano.edu.br/home/index.php/especializacoes.html

${ }^{4}$ Lei no 20.918 de 21 de dezembro de 2020 (site da Seduce Goiás).
} 
Gráfico 6: Tempo de serviço.

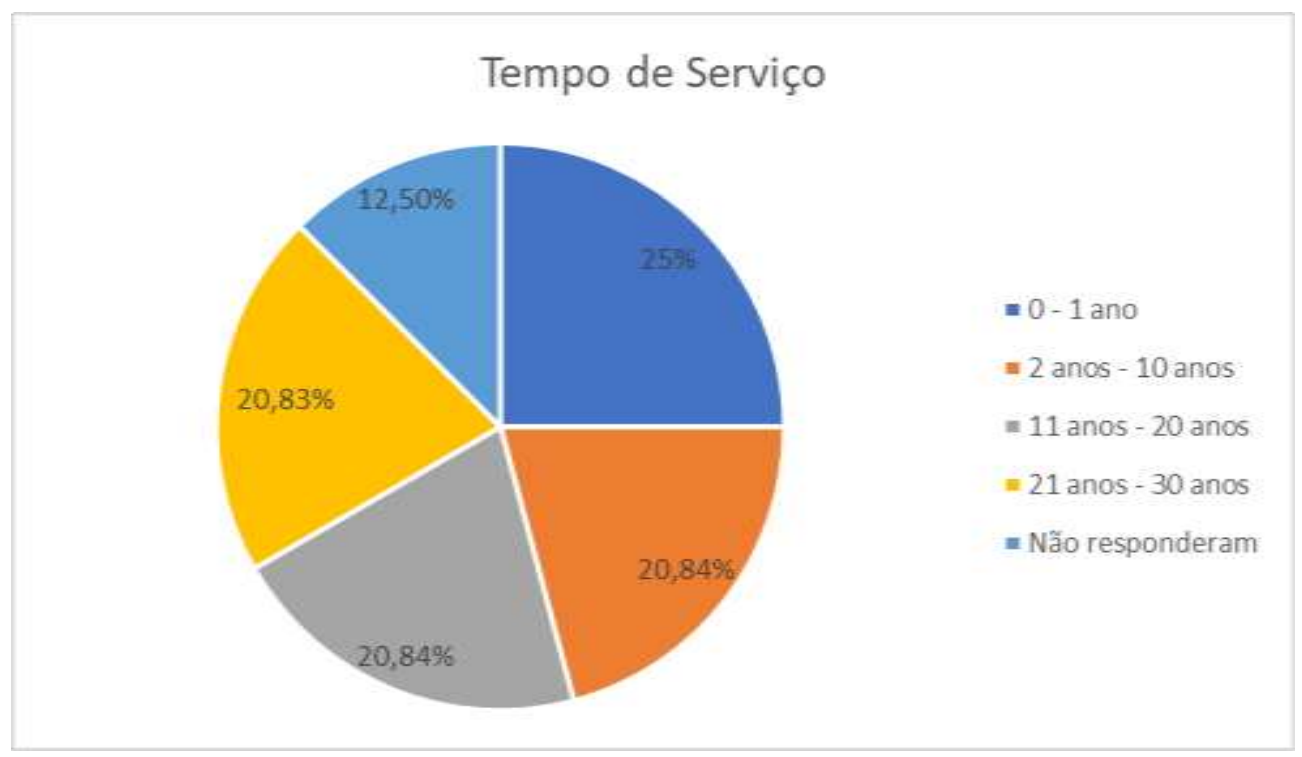

Fonte: Dados da Pesquisa (2020).

No Gráfico 7, verifica-se a participação dos docentes em formação continuada oferecida pela Secretaria de Estado da Educação nos anos de 2018 e 2019, demonstrando que no ano de 2018, 70,83\% dos professores da Unidade Escolar pesquisada, não participaram de alguma formação continuada e 29,17\% dos professores participaram de alguma formação continuada oferecida pela Secretaria de Estado da Educação. Em 2019: 75\% dos professores não participaram de formação continuada oferecida pela Secretaria de Estado da Educação e 25\% dos professores participaram de alguma formação continuada oferecida pela Secretaria de Estado de Educação.

Gráfico 7: Participação em formações continuadas oferecidas pela Secretaria de Estado da Educação.

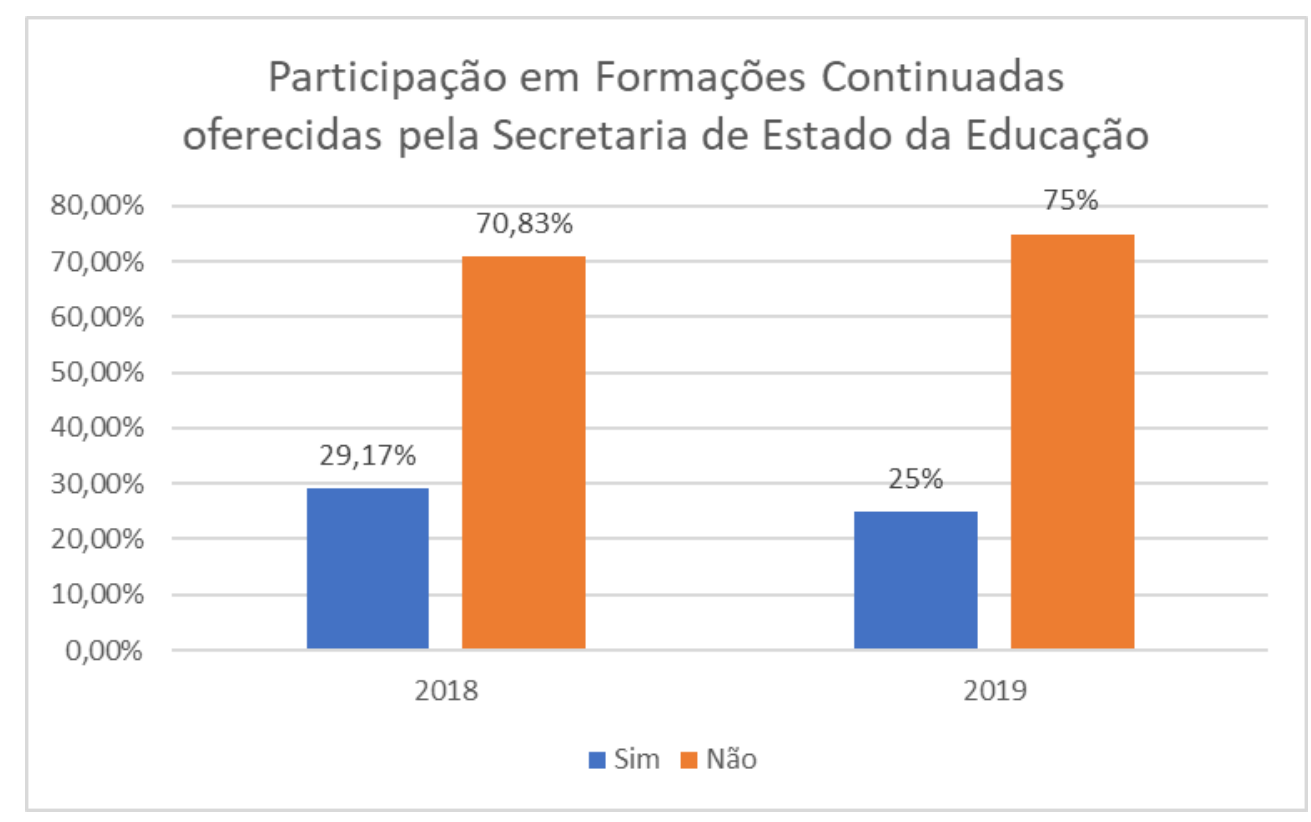

Fonte: Dados da Pesquisa (2020). 
Já o Gráfico 8, mostra que 91,66\% dos professores da Unidade Escolar pesquisada, não participaram de nenhuma formação continuada oferecida por outras instituições nos anos de 2018 e 2019 e 8,34\% dos professores participaram de alguma formação continuada nos anos de 2018 e 2019.

Gráfico 8: Participação em formações continuadas oferecidas por outras instituições nos anos de 2018 e 2019.

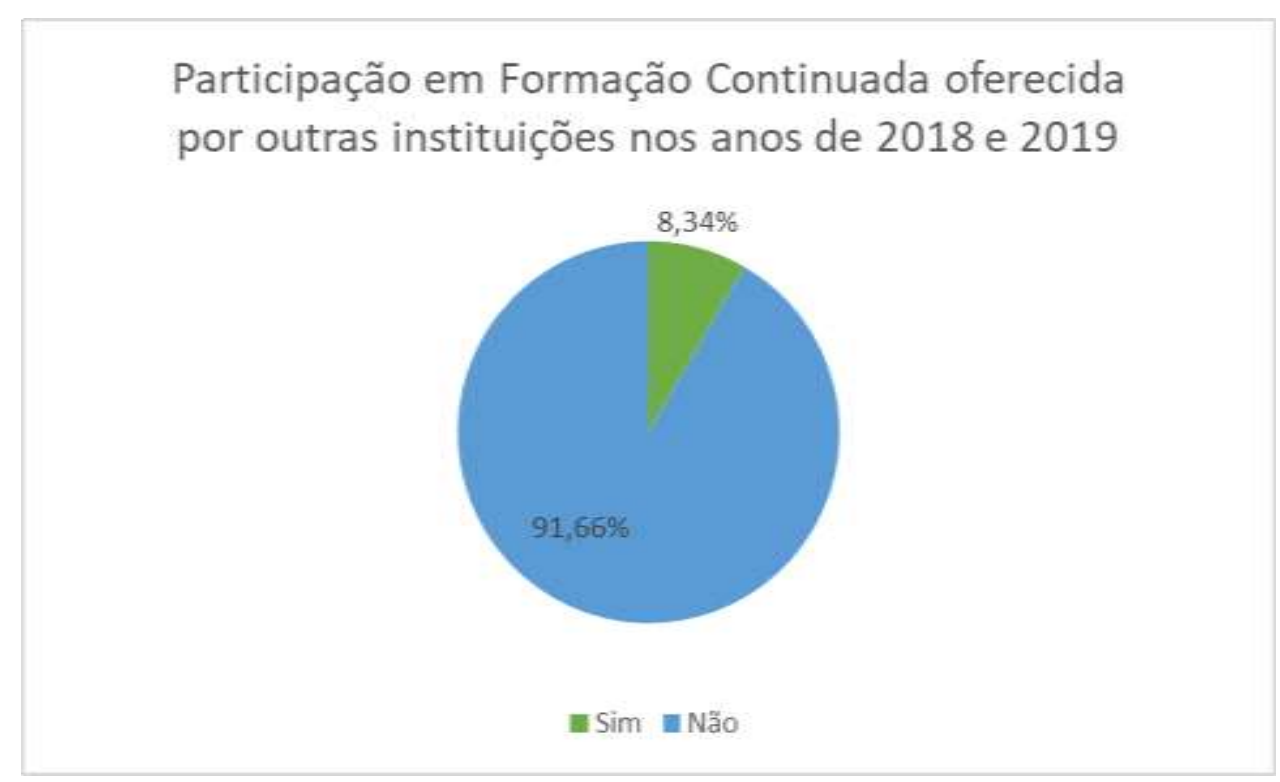

Fonte: Dados da Pesquisa (2020).

É importante que os programas de formação levem em consideração os vários fatores que implicam no desenvolvimento das práticas pedagógicas e no processo do trabalho docente. Segundo Nóvoa (1995), a formação continuada é a saída possível para a melhoria da qualidade do ensino, dentro do contexto educacional contemporâneo.

No Gráfico 9, verifica-se que 66,66\% dos professores da Unidade Escolar pesquisada leram livros para a sua reflexão pedagógica nos anos de 2018 e 2019 e 33,34\% dos professores da Unidade Escolar pesquisada não leram nenhum livro para reflexão de sua prática pedagógica, sejam livros didáticos de sua área de atuação ou livros paradidáticos.

Gráfico 9: Livros lidos para reflexão das práticas pedagógicas em sala de aula nos anos de 2018 e 2019.

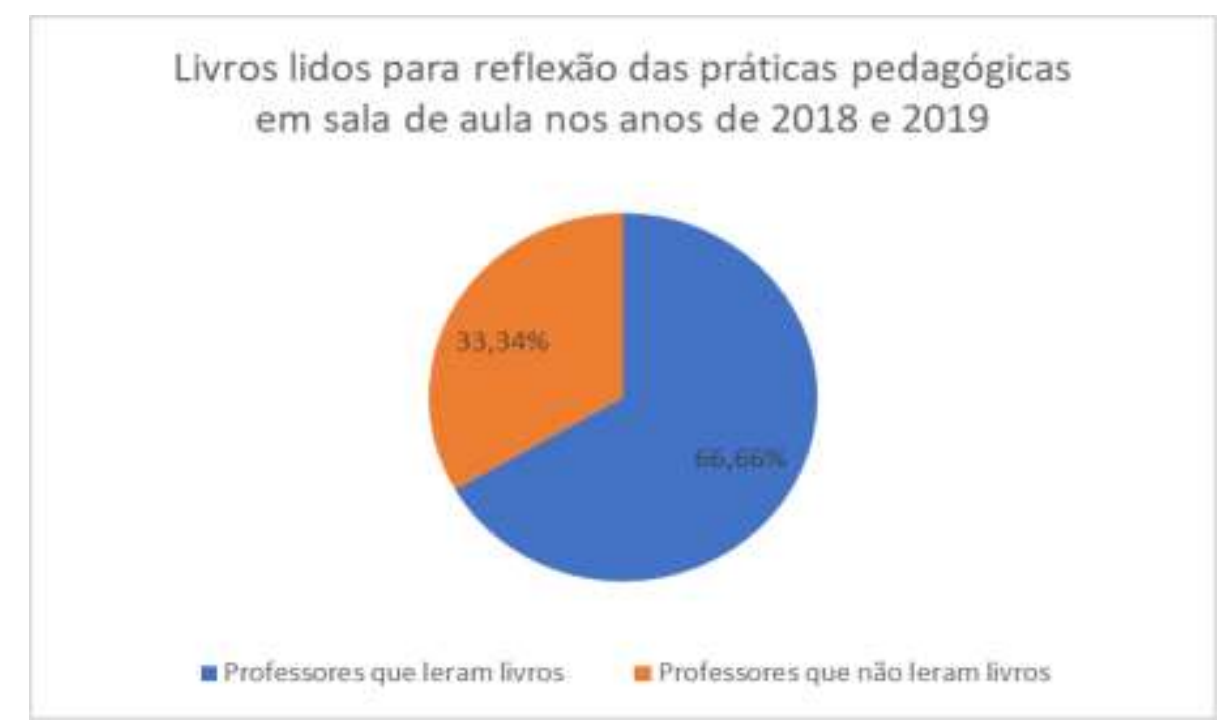

Fonte: Dados da Pesquisa (2020). 
No Gráfico 10, é possível perceber que 75\% dos professores da Unidade Escolar pesquisada não possuem experiência em seguir algum autor em sua prática pedagógica e $25 \%$ dos professores da Unidade Escolar pesquisada possuem experiência em seguir os ensinamentos propostos por autores em suas práticas pedagógicas.

Para Lima (2001, p. 30), a formação continuada é a articulação entre o trabalho docente, o conhecimento e o desenvolvimento profissional do professor com possibilidade de postura reflexiva dinamizada pela práxis. Esse pensamento só acontecerá quando houver a relação entre o conhecimento dialogado no processo de formação com a prática do professor e seu desenvolvimento profissional.

Gráfico 10: Experiência em seguir algum autor na prática pedagógica do entrevistado.

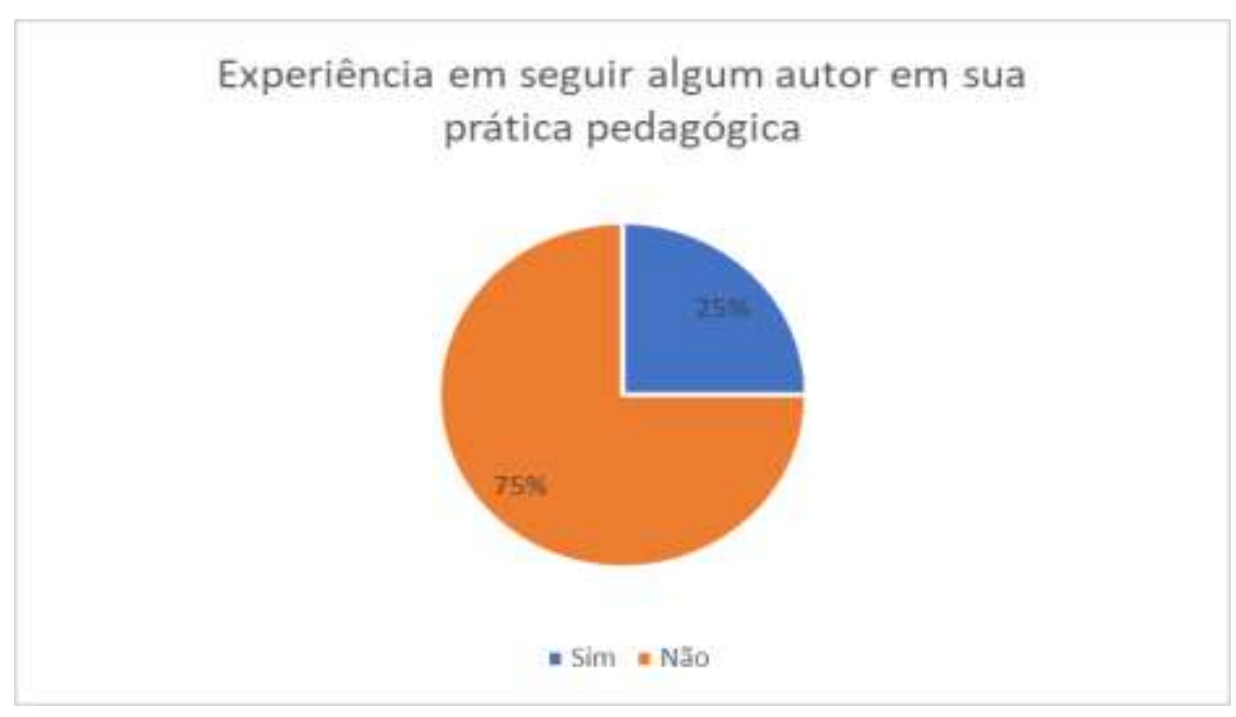

Fonte: Dados da Pesquisa (2020).

Já os dados obtidos no Gráfico 11, demonstram que 58,33\% dos professores da Unidade Escolar pesquisada trabalham de 26 horas a 40 horas semanais; 29,16\% trabalham de 42 horas a 60 horas semanais e 12,5\% dos professores não responderam a sua carga horária semanal. O baixo salário, a rotina desgastante e a desvalorização social fazem com que o professor não tenha tempo e disposição para a formação continuada.

Gráfico 11: Carga horária semanal.

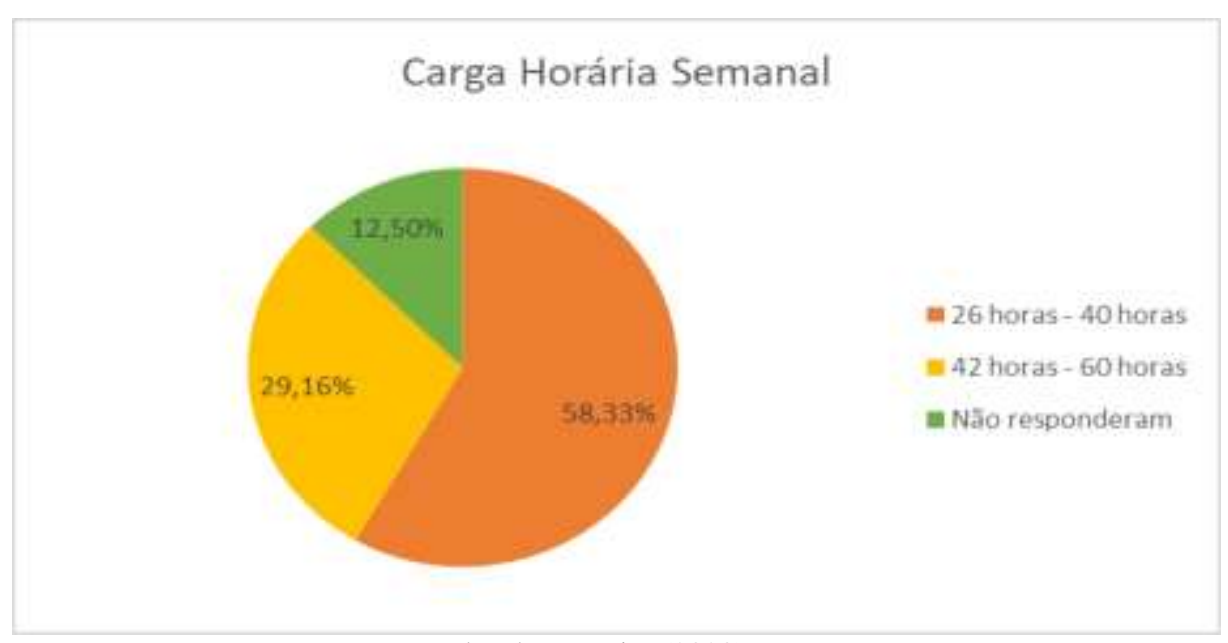

Fonte: Dados da Pesquisa (2020). 
Este Gráfico, confirma as hipóteses dos fatores relacionados ao professor: rotina intensa com carga horária alta e ausência de valorização salarial e social.

Os dados obtidos no Gráfico 12, demonstram que 87,5\% dos professores da Unidade Escolar não possuem disponibilidade de cursar formação continuada devido a sua alta carga horária semanal e 12,5\% dos professores da Unidade Escolar pesquisada, possuem disponibilidade de cursar uma formação continuada com a carga horária semanal que exercem na função de magistério.

Gráfico 12: Com a carga horária disponível há tempo para cursar alguma formação continuada.

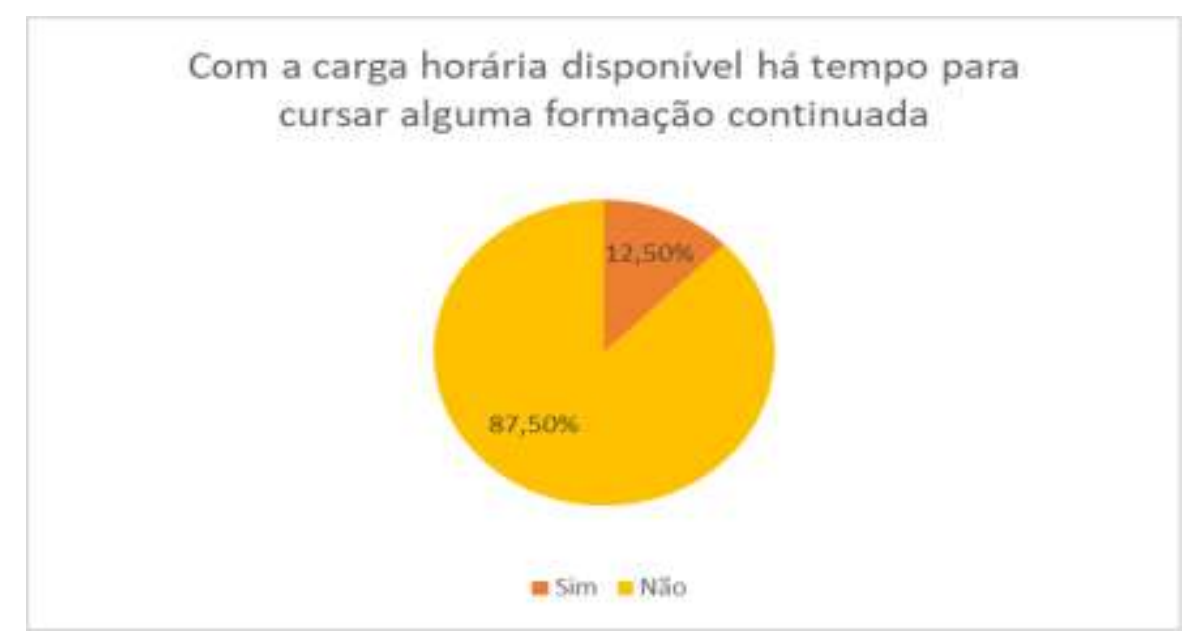

Fonte: Dados da Pesquisa (2020).

Os dados obtidos do Gráfico 13, demonstraram que 54,16\% dos professores da Unidade Escolar pesquisada, responderam que a formação continuada interfere em suas práticas pedagógicas e 45,84\% dos professores da Unidade Escolar pesquisada, responderam que a formação continuada não interfere em suas práticas pedagógicas.

Gráfico 13: A formação continuada interfere em suas práticas pedagógicas.

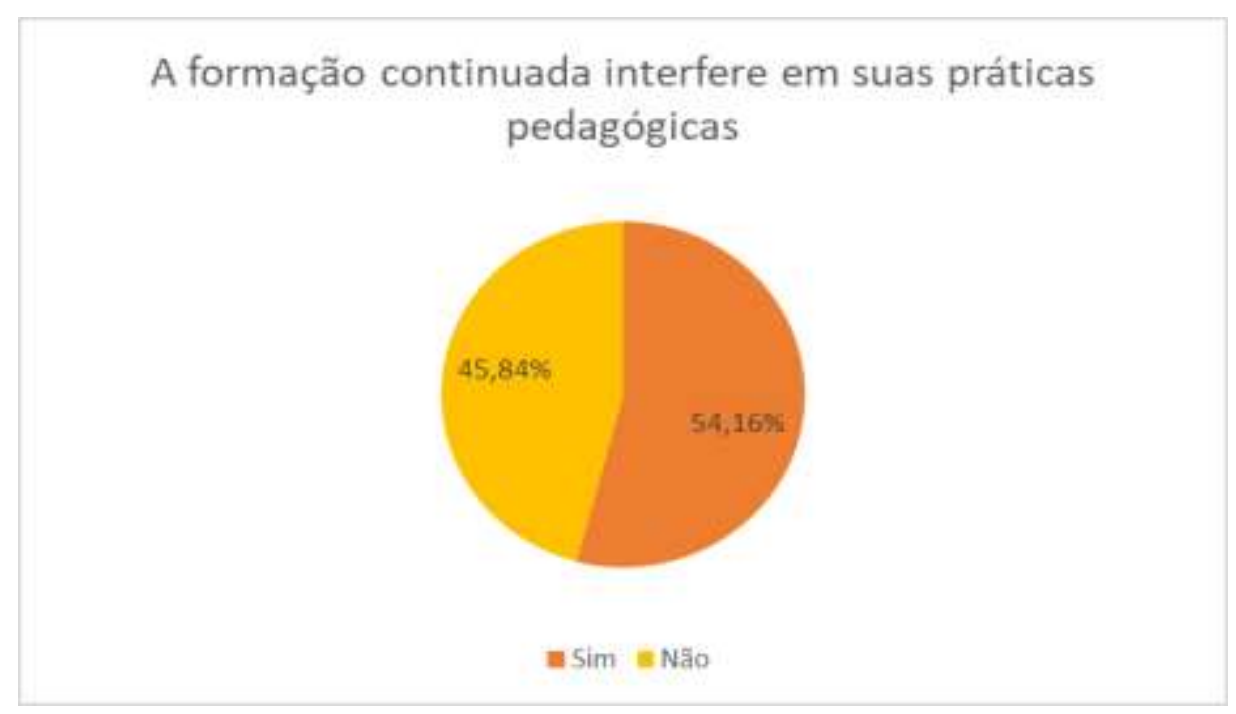

Fonte: Dados da Pesquisa (2020). 
No Gráfico 14 verifica-se que 70,84\% dos professores da Unidade Escolar pesquisada, exercem a função de Magistério exclusivamente na Unidade Escolar pesquisada e 29,16\% dos professores trabalham em outras Unidades Escolares.

Gráfico 14: Trabalha apenas na escola pesquisada.

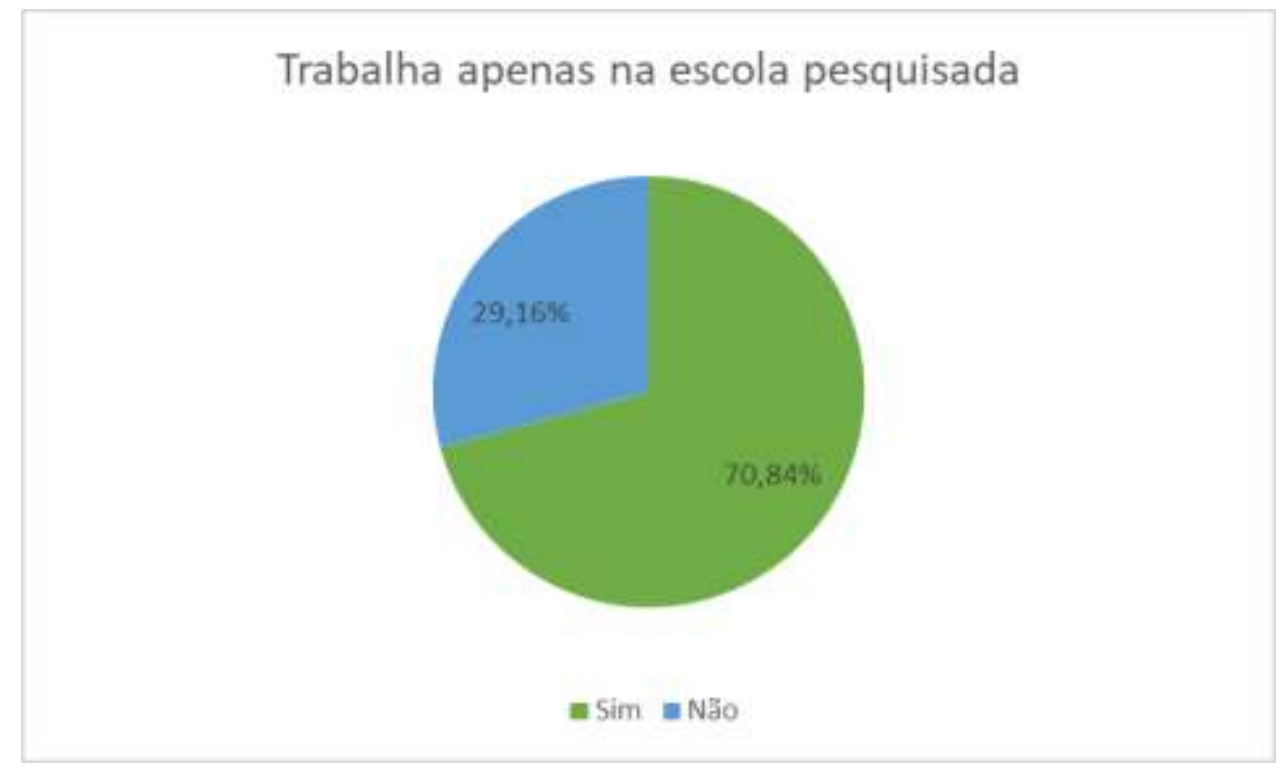

Fonte: Dados da Pesquisa (2020).

Nóvoa (1992) entende e defende a formação dos professores como um processo contínuo e fundamental em suas vidas e na das escolas. O processo de formação não está acabado, mas se iniciou com o curso de graduação, sabendo que este saber produzido na Universidade não é algo mágico.

Percebe-se que, “...estar em formação implica investimento pessoal, um trabalho livre e criativo sobre os percursos e sobre os projetos próprios, com vistas à construção de uma identidade que é também uma identidade profissional" (Nóvoa, 1992, p. 25). Avaliar o seu trabalho, à crítica justa e objetiva, é o desejo do professor como desejo de acertar, de fazer o melhor.

Diante do resultado do questionário aplicado aos professores e aqui representados pelos gráficos, percebemos que romper com velhos paradigmas, não é tarefa fácil. A formação continuada é a possibilidade de mudanças de velhas práticas que não condizem com a realidade da contemporaneidade, que exige criatividade e renovação do pensamento para novas atitudes de transformação.

\section{Considerações Finais}

Este trabalho teve como finalidade pesquisar sobre a formação continuada em uma escola pública estadual no município de Santa Helena de Goiás-Goiás, com vinte e quatro professores que ali trabalham. A escolha desta escola foi por situar-se em um bairro que abrange outros bairros periféricos vulneráveis da cidade, com alto índice de criminalidade, prostituição e uso de entorpecentes, o último IDEB desta escola foi: 5,1, abaixo da projeção que era: 5,55.

O termo qualidade tem sido destacado na educação brasileira e constituí a síntese de preocupação de educadores e formuladores de políticas públicas da educação. Para assegurar padrões mínimos de aprendizagem dos alunos foram iniciadas políticas de avaliação educacional.

\footnotetext{
${ }^{5}$ https://novo.qedu.org.br/escola/52055272-ee-avelino-martins-rodrigues
} 
O Índice de Desenvolvimento da Educação Básica (IDEB) tem sido o instrumento de avaliação de caráter amostral que passou a produzir informações a respeito da realidade educacional brasileira, no intuito de fornecer subsídios para elaboração de políticas públicas que contribuam para a melhoria da qualidade da educação brasileira.

Com a necessidade de estabelecer padrões e critérios que sirvam para monitorar o sistema de ensino no Brasil, na busca por indicadores que pudessem medir o desenvolvimento das escolas brasileiras e o progresso dos programas colocados em prática pelo Estado, em 2007, o INEP (Instituto Nacional de Estudos e Pesquisas Educacionais Anísio Teixeira) criou o IDEB, o qual vem gerando seus dados e estudos educacionais e realiza levantamentos estatísticos e avaliativos em todos os níveis e modalidade de ensino (Fernandes, 2011).

Ao discutirmos as políticas escolares atreladas aos interesses do capital, é possível verificar, na perspectiva de Libâneo, Oliveira e Toschi (2010), que a educação de qualidade é aquela mediante a qual a escola deve promover a todos o domínio dos conhecimentos e o desenvolvimento de capacidades cognitivas e afetivas indispensáveis ao atendimento de necessidades individuais e sociais dos alunos, bem como a inserção no mundo e a constituição da cidadania, também como poder de participação, tendo em vista a construção de uma sociedade mais justa e igualitária, pois, na visão destes autores, qualidade é um conceito implícito à educação e ao ensino.

É imperioso que se desenvolvam esforços para determinar os objetivos e os meios ao seu alcance. O IDEB busca apontar alguns fatores necessários para se atingir índices elevados, entre os quais se destacam: enfrentar as deficiências igualmente significativas relacionadas ao projeto político-pedagógico, organização escolar, ensino e aprendizagem dos alunos, conselho escolar, reuniões com pais, diálogo com toda a comunidade escolar, entre outros, com vistas ao oferecimento da qualidade educacional. Primordialmente, é preciso focar no problema dos alunos que não concluem o ensino fundamental e médio (Belo \& Amaral, 2013). Logo, esse indicador permite uma ponte permanente de comunicação, devendo, por isso, orientar-se "pela transparência, atender ao direito à informação e ter em consideração outros princípios legais e éticos congruentes com as especificidades das situações [...” (Schneider; Nardi, 2014, p. 20).

A pergunta norteadora deste estudo foi: Quais motivos interferem à formação continuada e suas práticas pedagógicas em sala de aula, a partir das percepções dos professores da Unidade de Ensino da Rede Pública Estadual do município de Santa Helena de Goiás -Goiás nos anos de 2018 e 2019? Vários autores dialogaram para compor o referencial teórico desta pesquisa dentre eles: Nóvoa (1999), Tardif (2002), Freire (1979) e outros.

Como esta pesquisa envolveu seres humanos, se fez necessário após assinatura de todos os documentos para sua realização, a sua submissão ao Comitê de Ética, número do CAAE: 30225720.7.0000.0036, cujo parecer de aprovação ${ }^{\circ}$ 4.254.742 datado em 02 de Setembro de 2020. A metodologia foi pautada com abordagem quantitativa com caráter exploratório, desenvolvida com a participação de vinte e quatro professores com faixa etária de 18 a 61 anos, que após à leitura do TCLE (Termo de Consentimento Livre e Esclarecido), iniciou-se a pesquisa com um questionário com dezenove perguntas abertas e de livre escolha.

As Metas 15 e 16 do Plano Nacional de Educação-PNE 2014-2024, anexo à Lei 13005/14; a LDB- Lei 9.394; Diretrizes Curriculares nacionais para a Formação de Professores da Educação Básica e a Rede Nacional de Formação Continuada de Professores garantem a formação continuada dos professores no Brasil. Na seção resultados e discussão verifica-se a importância da formação continuada de professores como meio de assegurar a atuação em sala de aula preparados e capacitados. Para ilustrar a pesquisa realizada foram usados gráficos, com os resultados do questionário com dezenove perguntas abertas e com múltipla escolha.

$\mathrm{Na}$ Unidade Escolar pesquisada a maioria dos docentes são mulheres, há apenas um docente do sexo masculino. A idade prevalecente dos docentes é de 20 a 60 anos. No Brasil, o professor infelizmente não é valorizado, às vezes recebem 
menos que o piso salarial proposto que é de R $\$ 2.886,24$. Por tratar-se de escola pública estadual, os professores são pagos pelo Estado com a remuneração de $\mathrm{R} \$ 1800,00$ a $\mathrm{R} \$ 10.000,00$.

O último processo seletivo fora realizado em 2020, para as áreas de cadastro reserva nas áreas de: Matemática, Biologia e Química, as outras áreas não foram contempladas. Quanto à formação inicial dos docentes da Unidade Escolar pesquisada a maioria possui graduação em área específica em que ministram suas aulas, os outros estão cursando faculdade.

Em nossa região há o oferecimento de cursos de formação continuada para os professores, oferecidos de forma pública e gratuita com as especializações lato sensu e stricto sensu oferecidas pela UFJ, IF Goiano, UFG, IF Goiás, UEG etc.

$\mathrm{Na}$ Unidade Escolar pesquisada há muitos professores contratados temporariamente segundo a Lei no 20.918 de 21 de Dezembro de 2020 que estendeu o prazo dos contratos temporários para até 05 anos de permanência na SEDUCE (Secretaria de Estado da Educação de Goiás), onde segundo Novaes (2010) este fato revela uma das faces da precarização do trabalho docente no Brasil.

Os vinte e quatro docentes têm conhecimento básico para manusear o computador e os docentes regentes concursados exercem a função de magistério de 02 a 30 anos na Unidade Escolar pesquisada. Como o estudo principal desta pesquisa era a formação continuada dos professores nos anos de 2018 e 2019, os dados coletados e analisados demonstraram que foram oferecidas pouquíssimas formações continuadas pela SEDUCE (Secretaria de Estado da Educação de Goiás) aos professores e estes também não participaram de formações continuadas oferecidas por outras Instituições.

Diante de toda conjuntura, esperamos com este estudo demonstrar possíveis motivos da interferência ou contribuição da formação continuada das práticas pedagógicas em sala de aula a partir das percepções dos professores da Unidade Escolar pesquisada e possibilitar mudanças nas práticas pedagógicas dos docentes com a formação continuada.

\section{Referências}

Almeida, M. E. de. (2000). Proinfo Informática e formação de professores. Secretaria de Educação a Distância. Brasília: Ministério da Educação, SEED, Série de Estudos. Educação a Distância.

Barbosa, S. H. P. B. \& Fernandes, C. S. G. (2018). A teoria do professor reflexivo na formação continuada de professores: discurso vazio de conteúdo. Revista Eletrônica de Educação. 12(1), 6-19.

Belo, F. \& Amaral, N. C. (2013). IDEB da Escola: a aferição da qualidade do ensino tem sido referencial para se (re) pensar a educação municipal? Revista Educação e Políticas em Debate, 2(2),339-353.

Brasil. (1996). Lei $n^{\circ}$ 9.394, de 20 de dezembro de 1996. Estabelece as Diretrizes e Bases da Educação Nacional. Diário Oficial da União. Brasília.

Brasil. (1996). Lei $n^{o}$ 13.005, de 25 de junho de 2014. Aprova o Plano Nacional de Educação - PNE e dá outras providências. Diário Oficial [da] República Federativa do Brasil, Brasília.

Brasil. (2021). INEP - Censo do Professor. 2021.

Brasil. (2006). Ministério da Educação. Rede Nacional de Formação Continuada de Professores da Educação Básica. Brasília: MEC/Secretaria de Educação Básica.

Brasil. (1996). LDB de 9.394 de 20 de dezembro de 1996. Estabelece as diretrizes e bases da educação nacional.

Brasil. (2007). O PDE: razões, princípios e programas brasileiros.

Brasil. (2007). IDEB: como melhorar os índices.

Brasil. (2001). MEC/CNE/CP. Parecer nº 009, de 08 de maio de 2001. Diretrizes Curriculares Nacionais para a Formação de Professores da Educação Básica, em nível superior, curso de licenciatura, de graduação plena. Brasília/DF.

Brasil. (2004). Rede Nacional de Formação Continuada de Professores da Educação Básica: orientações gerais.

Capucho, V. (2012). Educação de jovens e adultos: práticas pedagógicas e fortalecimento da cidadania. Cortez.

Cavaco, M. H. (1995). Ofício do professor: o tempo e as mudanças. In: Nóvoa, A. (Eds). Profissão professor. (2a ed.), Porto Editora.

Feldmann, M. G. (2003). Questões contemporâneas: mundo do trabalho e democratização do conhecimento. In: Severino, A. J.; Fazenda, I. Políticas educacionais: o ensino nacional em questão. Papirus. 
Research, Society and Development, v. 10, n. 16, e324101623381, 2021

(CC BY 4.0) | ISSN 2525-3409 | DOI: http://dx.doi.org/10.33448/rsd-v10i16.23381

Fernandes, R. (2011). Índice de desenvolvimento da Educação Básica (IDEB): metas intermediárias para a sua trajetória no Brasil, estados, municípios e escolas.

Figueiredo, R. V. (2002). Políticas de inclusão - Escola, gestão da aprendizagem na diversidade. Políticas organizativas e curriculares: Educação inclusiva e formação de professores. Rio de Janeiro: DPSA.

Forquim, J. C. (1993). Escola e cultura. Artes Médicas.

Freire, P. (1975). Pedagogia do oprimido. Paz e Terra.

Freire, P. (1979). Conscientização: teoria e prática da libertação. Cortez e Moraes.

Freire, P. (1996). Pedagogia da autonomia: saberes necessários à prática educativa. (7a ed.), Paz e Terra.

Gil, A. C. (2009). Como elaborar projetos de pesquisa. (4a ed.), Atlas.

Gil, A. C. (2016). Métodos e técnicas de pesquisa social. (6a ed.), GEN: Atlas.

Gimeno, S. J. (1999). Poderes instáveis em educação. Artmed Sul.

Grossi, M. P. (2004). Masculinidades: Uma revisão teórica, antropologia em primeira mão. UFSC.

Huberman, M. (1989). Les phases de la carrière enseignante: un essai de description et de prévision. RevueFrançaise de Pédagogie, 86(1), 5-16.

Imbernón, F. (2001). Formação docente e profissional: formar-se para a mudança e a incerteza. Cortez.

Libâneo, J. C.; Oliveira, J. F. \& Toschi, M. S. (2010). Educação escolar: políticas, estrutura e organização. (2a ed.), Cortez.

Lima, M. S. L. (2001). A formação contínua dos professores nos caminhos e descaminhos do desenvolvimento profissional. Doutorado em Educação. Faculdade de Educação da Universidade de São Paulo (FEUSP).

Louro, G. L. (1997). Gênero e magistério: identidade, história, representação. In: Catani, D. et al.(org.) Docência, memória e gênero: estudos sobre formação. São Paulo: Escrituras Editora.

Marcelo, C. (2009). El professorado principiante: insercion a la docência. España.

Moreira, C. E. (2002). Formação continuada de professores: entre o improviso e a profissionalização. Insular.

Nóvoa, A. (1992). Os professores e sua formação. Dom Quixote/IIE.

Nóvoa, A. (1992). Organizações escolares em análise. Lisboa: Dom Quixote/IIE.

Nóvoa, A. (1995). Os professores e as Histórias da sua vida. In: Nóvoa, A. Vidas de professores. (2a ed.), Porto Editora.

Nóvoa, A. (1999). Profissão professor. Porto.

Piccinini, C. et al. (2014). PNE e Trabalho Docente: formação, forma(ta)ção e (con)formação. In: Jornada do Histedbr e Seminário de Dezembro: A crise estrutural do capitalismo e seus impactos na educação pública brasileira.

Ribas, M. H. \& Carvalho, M. A. (1995). O caráter emancipatório de uma prática possível.

Schimidt, L. M.; Ribas, M. H. \& Carvalho, M. A. (1995). A prática pedagógica como fonte de conhecimento.

Schneider, M. P. \& Nardi, E. L. (2014). O IDEB e a construção de um modelo de accountability na educação básica brasileira. Revista Portuguesa de Educação, 27(1), 7-28.

Schön, D. A. (1987). Educating the reflective practitioner. Jossey-Bass.

Steffy, B. E. (1989). Career stages of classroom teachers. Technomic.

Tardif, M. (2002). Saberes docentes e formação profissional. Vozes.

Tozetto, S. S. (2013). O processo de formação continuada da docência. In: Raiman, A. Formação de professores e práticas educativas: outras questões. Ciência Moderna. 